\title{
AS ALTERAÇÕES DA LEI №. 13.465/2017 NA USUCAPIÃO ESPECIAL URBANA COLETIVA: QUESTÕES MATERIAIS E PROCESSUAIS
}

\section{THE CHANGES CAUSED BY THE LEGISLATION 13,465/2017 IN THE COLLECTIVE URBAN SPECIAL ACQUISITIVE PRESCRIPTION: SUBSTANTIVE AND PROCEDURAL ISSUES}

\author{
Gilberto Fachetti Silvestre ${ }^{1}$
}

\section{Resumo:}

Analisa os impactos da Lei no. 13.465/2017 (Reurb) na usucapião especial urbana coletiva do Estatuto da Cidade. Para averiguar as mudanças, parte de uma visão panorâmica preliminar sobre o instituto para, posteriormente, analisar em detalhes as alterações específicas promovidas pela novel legislação. O objetivo da pesquisa é revelar que os principais impactos foram nos requisitos subjetivos da usucapião coletiva e no procedimento de declaração da prescrição aquisitiva, uma vez que doravante é possível a usucapião pela via administrativa. A revisão bibliográfica pretende orientar a operabilidade do instituto após a Reurb. Para tanto, procedeu-se a uma análise documental basicamente dos diplomas legislativos, pois a literatura jurídica sobre a temática ainda é escassa. Dada a recente vigência da lei de 2017, ainda não se verifica julgados nos tribunais de apelação e na instância superior e suprema que possam oferecer precedentes e elementos de convicção. A pesquisa desenvolve fundamentos jurídicos e argumentos que levam a concluir que a nova lei foi salutar e aperfeiçoou a operabilidade da usucapião coletiva, revigorando seu papel como elemento de regularização fundiária, atribuição de propriedade privada e concretização do direito fundamental de moradia.

Palavras-chave: Usucapião coletiva. Lei no. 13.465/2017. Alterações. Procedimento. Usucapião extrajudicial.

\footnotetext{
1 Professor da Universidade Federal do Espírito Santo (UFES). Doutor em Direito Civil pela Pontifícia Universidade Católica de São Paulo (PUC/SP). Mestre em Direito Processual Civil pela Universidade Federal do Espírito Santo (UFES). Advogado. Instituição: Universidade Federal do Espírito Santo (UFES), Espírito Santo. Brasil. Área: Direito Civil, Direito Processual Civil. E-mail: gilberto.silvestre@ufes.br
} 


\section{Abstract:}

This research intended to analyze the impacts of the legislation n. 13,465/2017 (Reurb) in the collective urban special acquisitive prescription of the City's Statute. To analyze the changes, the research parted from a preliminary overview of the institute to later analyze in detail the specific changes promoted by the novel legislation. The research carried out revealed that the main impacts are on the subjective requirements of the collective acquisitive prescription and on the procedure for declaring the acquisitive prescription, since it is now possible to use acquisitive prescription through administrative channels. The main objective of the research was to carry out a bibliographic review that could guide the operability of the institute after Reurb. In order to do so, it was basically carried out a documentary analysis of the legislative acts, since the legal literature on the subject is still scarce. Given the recent validity of the 2017 legislation, there are not yet any decisions in courts of appeal and in higher courts that can provide precedents and elements of conviction. The research develops legal bases and arguments that lead to the conclusion that the new legislation was salutary and perfected the operability of the collective acquisitive prescription, reinvigorating its role as element of land regularization, attribution of private property and realization of the fundamental right of housing.

Keywords: Collective acquisitive prescription. Legislation 13,465/2017. Changes. Procedure. Extrajudicial acquisitive prescription.

\section{INTRODUÇÃO}

A usucapião especial urbana coletiva foi substancialmente modificada em 2017, embora tenha sido mantida sua essência e razão de ser.

De 2001 a 2017 a usucapião coletiva tem seu regime jurídico basicamente concentrado nos arts. 10 a 14 da Lei no. 10.257/2001 (Estatuto da Cidade). Tal usucapião, porém, sofreu significativas modificações nesse regime jurídico a partir da Lei no. 13.465/2017, conhecida como Lei da Regularização Fundiária Urbana (Reurb). Além de modificar os conceitos e requisitos fundamentais, essa lei criou a possibilidade de se declarar a usucapião pela via extrajudicial (art. 216-A da Lei no. 6.015/1973).

Nesse sentido, essa pesquisa se preocupou em explicar como era, como está e como pode ficar a usucapião coletiva neste primeiro momento da transição de um regime jurídico para o outro. Ou seja, essa pesquisa trabalhou com as bases teóricas e dogmáticas que orientam a nova maneira de proceder em torno do instituto. 
Preliminarmente se questionou quais as diferenças entre a antiga e a novel normativa, para posteriormente avaliar se tais alterações, a partir de uma perspectiva teórica, colaboram ou não para a concretização do instituto e de seus propósitos legislativos (ratio legis).

A pesquisa foi executada seguindo basicamente uma metodologia de análise de documentos literários e judiciais. Nesse aspecto, foi uma pesquisa qualitativa, pois analisou os fundamentos e efeitos verificados nas amostragens daqueles documentos. Houve, ainda, uma pesquisa qualiquantitativa de julgados do Superior Tribunal de Justiça objetivando verificar se há jurisprudência, ou apenas julgados isolados ou precedentes em torno da matéria.

Ainda quanto à metodologia, empregou o método dedutivo, tendo por premissa maior considerada verdadeira que a nova lei sanou as deficiências, dúvidas e dificuldades da disciplina jurídica anterior, e por segunda premissa, a possibilidade de ampliar o espectro de aplicação da usucapião coletiva a partir da Reurb.

A contribuição que essa pesquisa pretende dar ao desenvolvimento do conhecimento jurídico é oferecer argumentos iniciais ao debate teórico e dogmático em torno da nova normativa, com fundamento em interpretação sistemática da Lei no. 10.257/2001, da Lei no. 13.465/2017, Lei no. 6.015/1973, do Código de Processo Civil, da Constituição da República Federativa do Brasil e do Código Civil, para favorecer a aplicação da usucapião coletiva.

Um juízo epistemológico preliminar levanta como hipótese que os principais impactos da Lei no. 13.465/2017 na operabilidade do instituto foram nos requisitos subjetivos da usucapião coletiva e no procedimento de declaração da prescrição aquisitiva, uma vez que doravante é possível a usucapião pela via administrativa. O objetivo da pesquisa, portanto, é revelar se essa hipótese se confirma ou não. E, se confirmada, quais seus impactos na concretização do direito e da regularização fundiária.

Essa é uma pesquisa dividida em duas fases. Na primeira delas - que ora se apresenta foca-se em uma análise "técnica" (rectius: dogmática) da nova sistemática da usucapião coletiva. 0 foco é a operabilidade das normas da Lei ㄲo. 13.465/2017 e da Lei №. 10.257/2001. Inicialmente, demonstra-se como a nova sistemática proporciona o direito à moradia digna.

Caberá, porém, à segunda fase da pesquisa refletir sobre a estatura desse instrumento de Direito Urbanístico, e sobre como essa normativa realiza os elementos centrais que orientam tal ramo do Direito, a exemplo da função social da cidade e da propriedade.

Hoje, a usucapião coletiva se tornou instrumento de regularização de aglomerações habitacionais e comerciais urbanas. Não é mais - apenas - um instrumento de política pública para atender exclusivamente a pessoas em vulnerabilidade socioeconômica (população carente). Aplica- 
se, pois, a qualquer pessoa em um núcleo urbano informal. Isso não retira, porém, o caráter de direito coletivo do instituto, que permanece podendo ser operacionalizado por ações coletivas.

\section{DEFINIÇÃO E FUNDAMENTOS LEGAIS DA USUCAPIÃO ESPECIAL URBANA COLETIVA}

Em uma definição geral, a usucapião (lato sensu) é um modo originário de aquisição de propriedade e de outros direitos reais, consolidando os poderes que se têm sobre a coisa para além da posse, geralmente refletido nas faculdades de usar, fruir, dispor e reobter (reivindicar). Todo direito real se expressa por meio desses poderes, mas em diferentes graus, ora compreendendo todos (propriedade e laje), ora sofrendo algumas limitações (como na habitação, no uso, no usufruto etc.). A usucapião permite a aquisição da propriedade por um sujeito (usucapiente) e, por consequência, implica na perda da propriedade pelo titular registral (pro forma) deste direito (usucapido), o qual perderá as faculdades (domínio) definitivamente e a propriedade sobre a coisa.

A usucapião especial urbana coletiva, por sua vez, foi introduzida no ordenamento jurídico brasileiro pela Lei no. 10.257/2001, mais conhecida como Estatuto da Cidade, especificamente no art. 10. O objetivo primário dessa usucapião foi atender ao comando constitucional de adoção de políticas de regularização do espaço urbano nos Municípios, além da concretização do direito fundamental à moradia e da função social da propriedade (art. 182 da Constituição da República Federativa do Brasil). Tratou-se (e se trata) de um instrumento de aquisição e regularização da propriedade privada de comunidades, sobre terreno de outrem localizado na zona urbana.

Em linhas gerais, a usucapião coletiva ocorre quando uma "população" possui como seu um imóvel localizado na cidade. (Não entenda "população", aqui, com aquele significado jurídico e político próprio da Teoria Geral do Estado, mas com o sentido de "grupo de pessoas").

Observe que o usucapiente não é uma pessoa em particular, mas pessoas coletivamente, isto é, um grupo de pessoas que esbulhou o imóvel. Justamente por isso, trata-se de uma usucapião plúrima.

O art. 10 da Lei no. 10.257/2001, antes da Lei №. 13.465/2017, referia-se ao usucapiente como "população". Entende-se por população, aqui, um conjunto de indivíduos que convive em uma determinada área geográfica em um determinado tempo. Sociologicamente, é um grupo com quantidade variável de pessoas que ocupam um local. Esses indivíduos constituem uma relação irmanada, pois estão unidos por interesses comuns e se submetem às mesmas condições de vida, especialmente as socioeconômicas. Não parece existir - pelo menos não sociologicamente - uma diferença entre os conceitos de comunidade e população. Uma comunidade é "um grupo territorial de indivíduos com relações recíprocas, que servem de meios comuns para lograr fins comuns" 
(FICHTER, 1973, pp. 153-155). Portanto, pode-se dizer que o usucapiente na usucapião especial urbana coletiva é uma comunidade ou uma população.

Com a alteração da redação do caput do art. 10 promovida pela Lei no. $13.465 / 2017$, passouse a utilizar o sintagma "núcleos urbanos informais": "Art. 10. Os núcleos urbanos informais existentes sem oposição há mais de cinco anos e cuja área total dividida pelo número de possuidores seja inferior a duzentos e cinquenta metros quadrados por possuidor são suscetíveis de serem usucapidos coletivamente, desde que os possuidores não sejam proprietários de outro imóvel urbano ou rural. [...]". O sintagma se encontra no plural para se referir a toda situação em que exista um núcleo urbano informal em determinados locais de uma cidade.

Existem, de acordo com o art. 11 da Lei no. 13.465/2017, três tipos de núcleos urbanos, quais sejam:

Art. 11. Para fins desta Lei, consideram-se:

I- núcleo urbano: assentamento humano, com uso e características urbanas, constituído por unidades imobiliárias de área inferior à fração mínima de parcelamento prevista na Lei no 5.868, de 12 de dezembro de 1972, independentemente da propriedade do solo, ainda que situado em área qualificada ou inscrita como rural;

II - núcleo urbano informal: aquele clandestino, irregular ou no qual não foi possível realizar, por qualquer modo, a titulação de seus ocupantes, ainda que atendida a legislação vigente à época de sua implantação ou regularização;

III - núcleo urbano informal consolidado: aquele de difícil reversão, considerados o tempo da ocupação, a natureza das edificações, a localização das vias de circulação e a presença de equipamentos públicos, entre outras circunstâncias a serem avaliadas pelo Município;

[...].

Apesar da alteração redacional, contudo, não há um afastamento entre os conceitos de núcleo urbano informal e população/comunidade. O núcleo é um conjunto de edificações, um loteamento, um condomínio, constituído por um conjunto de pessoas, ou seja, por uma população. (Lembrando que, aqui, população não tem o mesmo sentido da Teoria Geral do Estado). O conceito de núcleo tem a ver com a organização interna da ocupação do espaço territorial por um grupo de pessoas, as quais deverão ter algo em comum: 1) não serem proprietários de outro imóvel urbano ou rural; 2) exercerem a posse por pelo menos 5 anos; e 3) ocuparem uma fração ideal de até $250 \mathrm{~m}^{2}$ do espaço. Não mais se exige a pobreza como requisito especial.

A posse sobre o imóvel ou área é exercida em conjunto, tal qual ocorre, por exemplo, sobre as áreas comuns em um condomínio edilício. Isso é consequência da relação comunitária ou irmanada entre os indivíduos. Tanto é assim que, antes da Lei no. 13.465/2017, essa usucapião ocorria onde não seria possível identificar os terrenos ocupados por cada possuidor. 
Por essa razão, a usucapião coletiva, quando reconhecida, cria um condomínio, pois todos os membros do grupo comunitário adquirem a propriedade sobre todo o imóvel. A situação condominial está prevista nos §§ 3o a 5으 da Lei no. 10.257/2001.

\section{O IMPACTO DA LEI №. 13.465/2017 NOS REQUISITOS ESPECIAIS DA USUCAPIÃO COLETIVA}

Podem-se destacar dois grupos de requisitos dessa modalidade de usucapião. A primeira categoria é a dos requisitos gerais. Trata-se daqueles elementos configuradores de toda usucapião: coisa hábil, posse, tempo e animus domini. Não serão abordados nessa pesquisa. A segunda categoria é constituída por elementos exigidos tão somente para a usucapião, pois essa modalidade de usucapio tem requisitos que lhe são próprios, para além daqueles gerais de toda usucapião.

A Lei №. 13.465/2017 alterou substancialmente os requisitos especiais que foram previstos primitivamente no Estatuto da Cidade (Lei no. 10.257/2001). Por isso, parece necessária uma comparação entre a novel formulação normativa do art. 10 e a anterior. De se observar, porém, que a alteração se encontra apenas no caput do art. 10; os parágrafos (1응ํㄱ) mantiveram suas redações originais:

\begin{tabular}{|l|l|}
\hline \multicolumn{1}{|c|}{ Antes da Lei no. 13.465/2017 } & \multicolumn{1}{|c|}{ Após a Lei no. 13.465/2017 } \\
\hline Art. 10. As áreas urbanas com mais de duzentos e & Art. 10. Os núcleos urbanos informais existentes \\
cinqüenta metros quadrados, ocupadas por & sem oposição há mais de cinco anos e cuja área \\
população de baixa renda para sua moradia, por & total dividida pelo número de possuidores seja \\
cinco anos, ininterruptamente e sem oposição, & inferior a duzentos e cinquenta metros quadrados \\
onde não for possível identificar os terrenos & por possuidor são suscetíveis de serem \\
ocupados por cada possuidor, são susceptíveis de & usucapidos coletivamente, desde que os \\
serem usucapidas coletivamente, desde que os & possuidores não sejam proprietários de outro \\
possuidores não sejam proprietários de outro & imóvel urbano ou rural. [...]. \\
imóvel urbano ou rural. [...]. & \\
\hline
\end{tabular}

Anteriormente à Lei ํo. 13.465/2017, exigia-se dos usucapientes posse pro misero e pro habitatio (ou pro morada), o que significa dizer que os possuidores deveriam ser pobres e ter o imóvel como moradia ("população de baixa renda para sua moradia"). Tais requisitos foram extintos do art. 10 do Estatuto das Cidades pela lei de 2017 que, a propósito, sequer exige posse pro labore para beneficiar os possuidores com a redução de prazo.

A nova redação do caput alterou substancialmente a sistemática dos requisitos da usucapião coletiva (HOSHINO, COELHO e MEIRINHO, 2017, pp. 981-984).

Antes da Lei no. 13.465/2017, tais requisitos podiam ser assim sistematizados:

$$
\begin{array}{l|l}
\text { Coisa } & \text { Imóvel urbano com área superior a } 250 \mathrm{~m}^{2}
\end{array}
$$




\begin{tabular}{|c|l|}
\hline $\begin{array}{c}\text { Usucapient } \\
\text { e }\end{array}$ & $\begin{array}{l}\text { População de baixa renda, composta por pessoas pobres na forma da } \\
\text { lei e que não tenham propriedade sobre outro imóvel urbano ou rural }\end{array}$ \\
\hline Posse & $\begin{array}{l}\text { Exercida de modo a não ser possível identificar as partes do imóvel } \\
\text { ocupadas individualmente pelos possuidores, ou seja, todos têm posse } \\
\text { sobre o todo }\end{array}$ \\
\hline Tempo & 05 anos \\
\hline
\end{tabular}

Para uma definição mais objetiva de população de baixa renda, pode-se aplicar o conceito de pobre da Lei no. 1.060/1950 ou das Defensorias Públicas dos Estados.

Após a Lei no. 13.465/2017 os requisitos passaram a ser os seguintes:

\begin{tabular}{|c|l|}
\hline Coisa & $\begin{array}{l}\text { Imóvel urbano no qual a divisão da área total pelo número de pessoas } \\
\text { seja igual ou menor a } 250 \mathrm{~m}^{2}\end{array}$ \\
\hline Usucapiente & $\begin{array}{l}\text { Núcleos urbanos informais, independentemente da condição de } \\
\text { hipossuficiência econômica das pessoas envolvidas. Contudo, tais } \\
\text { pessoas não podem ser proprietárias de outro imóvel urbano ou rural }\end{array}$ \\
\hline Posse & $\begin{array}{l}\text { Dividida entre as pessoas do núcleo de modo que cada um possua área } \\
\text { individual igual ou inferior a } 250 \mathrm{~m}^{2}\end{array}$ \\
\hline Tempo & 05 anos \\
\hline
\end{tabular}

O imóvel urbano usucapível poderá ser tanto um terreno quanto uma edificação. Um imóvel é urbano se localizado na região que o Plano Diretor Urbano do Município define como perímetro ou zona urbanos.

A novel formulação normativa extinguiu a hipossuficiência das pessoas como requisito para essa usucapião. Assim, os membros do núcleo informal não precisam ser pobres na forma da lei; basta que não sejam proprietários de outro imóvel urbano ou rural.

A nova redação resolveu, também, um problema de operabilidade do sistema anterior, que exigia a impossibilidade de identificar a área ocupada por cada morador para a configuração da usucapião coletiva. A partir da Lei no. 13.465/2017 a "confusão" na ocupação não é mais necessária, pois é possível usucapir coletivamente o imóvel urbano dividido em unidades, podendo estas terem titulares individualizados, desde que tal unidade não tenha área superior a $250 \mathrm{~m}^{2}$. Sobre esse problema, assim escrevem Thiago de Azevedo Pinheiro Hoshino, Bruno César Deschamps Meirinho e Luana Xavier Pinto Coelho (2017, pp. 981-982):

Segundo o art. 10 do Estatuto da Cidade, a usucapião coletiva pode ser promovida nas ocupações onde não for possível identificar os terrenos 
ocupados por cada possuidor. O requisito da impossibilidade de identificação dos terrenos tem sido considerado pela doutrina como uma exigência a ser interpretada de forma flexível, com vistas aos objetivos da regularização fundiária, e não para criar obstáculos ao exercício do direito, uma vez que, em última análise, sempre seria possível identificar, em algum grau, os limites da moradia de cada família [...].

Pela redação primitiva do caput do art. 10 do Estatuto da Cidade, mais parecia que essa usucapião ocorria quando todas as pessoas usavam o mesmo imóvel ao mesmo tempo, sem espaços próprios. A partir de 2017, no entanto, admite-se um loteamento ou divisão interna no núcleo urbano informal, com demarcações, exigindo-se uso coletivo apenas sobre áreas comuns.

\section{A LEGITIMIDADE ATIVA AD CAUSAM NA AÇÃO DE USUCAPIÃO ESPECIAL URBANA COLETIVA}

Georges Abboud (2008, p. 169) afirma que "o usucapião coletivo [sic] deve, necessariamente, ser observado sob o enfoque coletivo, na medida em que, de início, seu escopo é a defesa da própria comunidade".

Isso indica muito bem o que é a usucapião coletiva em essência: o direito das pessoas de um núcleo urbano informal de se tornarem proprietários de um imóvel urbano (terreno ou prédio). 0 direito de propriedade é, inicialmente, do grupo, e posteriormente haverá a divisão igualitária entre seus membros. Do contrário, seria a modalidade de usucapião especial urbana individual (art. 9o da Lei no. 10.257/2001).

Assim, deve-se caracterizar a usucapião coletiva como um direito transindividual e, posteriormente, verificar como se dá sua tutela judicial.

A usucapião coletiva é um direito coletivo?

Na década de 1980, o Brasil experimentou a implementação da Política Nacional do Meio Ambiente (Lei no. 6.938/1981), da Lei de Ação Civil Pública (Lei no. 7.347/1985) e do Código de Defesa do Consumidor (Lei no. 8.078/1990), além da já existente Lei da Ação Popular (Lei no. 4.717/1965). Essa legislação reconheceu o alcance de um direito em relação não só a um indivíduo, mas também em relação a um grande grupo de pessoas. Reconheceu, ainda, a existência de conflitos coletivos de ordem econômica, social ou cultural (VILLAS BÔAS e DAMASCENA, 2004, pp. 94-95). Tal reconhecimento é a materialização de direitos difusos, coletivos, individuais homogêneos e individuais. Isso porque os direitos podem ser individuais (quando o seu titular é um indivíduo determinado e isolado) ou transindividuais (quando o titular não é um indivíduo especificamente, mas uma coletividade). 
Os direitos individuais são os direitos subjetivos propriamente ditos, ou seja, aqueles cujo titular é determinado e isolado. São exemplos a propriedade particular, a vida, a privacidade, um crédito entre particulares.

Já os direitos transindividuais, metaindividuais ou ainda direitos coletivos lato sensu podem ser distribuídos em três categorias (SILVESTRE, 2018, pp. 248-255):

- $\quad$ Direitos difusos (art. 81, I do CDC): são indivisíveis, pois têm como titular não um sujeito determinado, mas a coletividade indeterminada, quer dizer, todas as pessoas em conjunto (GRINOVER, 1984, pp. 30-31). São aqueles transindividuais (pertencentes a vários indivíduos), de natureza indivisível (só podem ser considerados como um todo), e cujos titulares sejam pessoas indeterminadas (não se consegue sua individuação, nem mesmo como grupo) e ligadas por circunstâncias de fato (ZANETI JR., 2006, caps. 1 e 2; e ZAVASCKI, 1995, pp. 16-33). Sua principal característica é que tais direitos são massificados (pertencem à massa de sujeitos), e o prejuízo de sua violação atinge a todos. São exemplos: meio ambiente equilibrado, saúde, educação, qualidade de vida. Segundo Rodolfo de Camargo Mancuso (2000, pp. 45-93) eles constituem uma res communes omnium (e não uma res nullius), no sentido de que são "interesses de grupos integrados por uma pluralidade de pessoas indeterminadas, embora vinculadas por um mesmo interesse comum";

- $\quad$ Direitos coletivos (art. 81, /l do $C D C$ ): não são direitos de toda a sociedade, mas de certas categorias ou grupos sociais em que os indivíduos estão ligados a alguém por meio de um vínculo jurídico. São aqueles transindividuais, de natureza indivisível, de que seja titular grupo, categoria ou classe de pessoas (indeterminadas, mas determináveis enquanto grupo, categoria ou classe) ligadas entre si ou com a parte contrária por uma relação jurídica base que deve ser anterior à lesão) (ZANETI JR., 2006, caps. 1 e 2). Apresentam duas características elementares: 1) indeterminabilidade: a princípio, os indivíduos titulares desses direitos são indeterminados, mas poderão ser determinados (são determináveis); e 2) indivisibilidade: o direito é de todos do grupo, da categoria, logo não é possivel tratamento diferenciado, sendo os interesses da categoria tratados coletivamente. $\mathrm{O}$ exemplo clássico são as categorias profissionais representadas pelos sindicados ou as entidades de classe (Ordem dos Advogados do Brasil, Conselhos Profissionais) e os condôminos edilícios. Os direitos coletivos em sentido estrito e os individuais homogêneos correspondem a um grupo específico ou especificável; logo, o titular não é a sociedade como um todo tal qual ocorre nos direitos difusos -, mas um grupo de indivíduos ou uma categoria de pessoas; $\mathrm{e}$

- $\quad$ Direitos individuais homogêneos (art. 81, III do CDC): são direitos cujos titulares são, a priori, indeterminados. Tais direitos surgem após a ocorrência futura de um evento de origem comum, quando os sujeitos serão identificados e individualizados. Os sujeitos formam um grupo de vítimas comuns de um acontecimento; têm seus danos individuais, mas o direito é homogêneo. Daí a possibilidade de sua tutela se dar de forma coletiva (class action), comportando posterior identificação das vítimas e dos seus danos particulares (BARBOSA MOREIRA, 1984, pp. 195-196). As origens do instrumento processual para tutela dessa espécie de direito remontam às class actions for damages norte-americanas. Representam uma ficção criada pelo Direito positivo com a finalidade de possibilitar uma proteção coletiva 
(molecular) de direitos individuais com dimensão coletiva (em massa). São aqueles decorrentes de origem comum, ou seja, nascidos em consequência da própria lesão ou ameaça de lesão, em que a relação jurídica entre as partes é ex post factum (fato lesivo). O que têm em comum é a procedência, a "progênese" na conduta comissiva ou omissiva da parte contrária, geradora da lesão ou ameaça de lesão. O pedido nas ações coletivas será sempre uma tese jurídica geral que beneficie aos substituídos (as peculiaridades dos direitos individuais deverão ser atendidas em liquidação de sentença a ser procedida individualmente) (ZANETI JR., 2006, caps. 1 e 2).

Para José Carlos Barbosa Moreira (1984, pp. 193-196), esses interesses e direitos podem ser divididos em duas classes:

1. Direitos essencialmente coletivos: são os direitos difusos e os direitos coletivos em sentido estrito; $\mathrm{e}$

2. Direitos ontologicamente individuais que podem ser tutelados coletivamente: são os direitos individuais homogêneos. Nesse caso, segundo Humberto Theodoro Júnior e Juliana Cordeiro de Faria (2014, pp. 5-21), eles são tutelados coletivamente por uma questão de política legislativa da solução de conflitos. Por isso mesmo, designam tal classe de "direitos acidentalmente coletivos": "Quando, porém, se cogita de direitos individuais homogêneos, desde a origem se pode identificar a titularidade do direito pelo indivíduo, sem conotação alguma com o grupo que posteriormente se configurou apenas para efeito de atuação em juízo. São em realidade direitos individuais aos quais se dá tratamento processual coletivo. Ou seja, o direito subjetivo material é individual, a ele se dispensando, por razões de política legislativa, o uso de técnica processual coletiva para sua defesa. Trata-se, assim, de uma fiç̧ão jurídica criada para ampliar a defesa de direitos individuais de origem comum".

A partir dessas definições, é possível afirmar que a usucapião coletiva é um direito individual homogêneo com tratamento processual coletivo. Dessa maneira, a ação coletiva é um facilitador da tutela desse direito, mas não substitui a ação individual.

Não se trata de um direito essencialmente coletivo porque para sê-lo teria que ser indivisível, e a usucapião coletiva claramente não é. Para chegar a tal conclusão, os seguintes fundamentos legais:

- $\quad$ § 3o do art. 10 da Lei №. 10.257/2001: “Na sentença, o juiz atribuirá igual fração ideal de terreno a cada possuidor, independentemente da dimensão do terreno que cada um ocupe, salvo hipótese de acordo escrito entre os condôminos, estabelecendo frações ideais diferenciadas". Observe que se trata de um direito indivisível no primeiro momento, antes da sentença, mas na fase decisória se torna um direito individual homogêneo. Outrossim, esse dispositivo deixa clara uma necessária indicação do número de demandantes, situação de difícil constatação nos direitos coletivos stricto sensu por causa da expansão subjetiva da demanda;

- $\quad \S 4$ o do art. 10: permite concluir pela divisibilidade do direito, uma vez o condomínio especial poderá sofrer desmembramento e individualização: "O condomínio especial constituído é indivisível, não sendo passível de extinção, salvo deliberação favorável tomada por, no mínimo, dois terços dos condôminos, no caso de execução de urbanização posterior à constituição do condomínio"; 
- $\quad$ Caput do art. 10 da Lei no. 10.257/2001:

- um dos requisitos da usucapião é de ordem subjetiva, ou seja, depende de características individuais de cada possuidor, qual seja, não ser proprietário de outro imóvel urbano ou rural; e

- $\quad$ outro requisito é que cada possuidor exerça posse por no mínimo 5 anos ininterruptamente, isto é, para se tornar condômino, cada um dos membros do grupo deve ter posse nesse prazo; e

- $\quad$ Caput do art. 61 da Lei no. 13.465/2017: dentre as exigências que faz para a implantação do condomínio especial urbano, está a discriminação, na matrícula do condomínio, de cada parte do núcleo urbano informal ocupada pelas edificações: "Quando um mesmo imóvel contiver construções de casas ou cômodos, poderá ser instituído, inclusive para fins de Reurb, condomínio urbano simples, respeitados os parâmetros urbanísticos locais, e serão discriminadas, na matrícula, a parte do terreno ocupada pelas edificações, as partes de utilização exclusiva e as áreas que constituem passagem para as vias públicas ou para as unidades entre si". Mais uma vez aparece, aqui, a possibilidade de individuação do imóvel coletivamente usucapido.

Isso permite concluir que, embora a usucapibilidade se realize coletivamente, para que a usucapião coletiva se implemente será necessário atender a requisitos individuais e particulares de cada sujeito possuidor pertencente ao grupo. Logo, tal direito é sim divisível entre os possuidores, quais sejam, aqueles que reúnem os requisitos legais para usucapir.

A indivisibilidade não é da usucapião coletiva, mas do condomínio especial constituído a partir da declaração de usucapião coletiva.

Para Benedito Silvério Ribeiro (2010, p. 1.043), a usucapião coletiva é um direito individual homogêneo:

A ação de usucapião coletiva exige que os interesses individuais sejam homogêneos, isto é, que procedam das mesmas circunstâncias de fato, portanto, que tenham origem comum. Os interesses devem ser de grupo determinável, e os direitos são divisíveis, observando-se os quinhões, que podem variar, mas que encontram um limite (até $250 \mathrm{~m}^{2}$ para cada qual). É possível que para algum dos ocupantes reste a ação improcedente, vindo a não satisfazer os requisitos legais (não prova de ocupação por cinco anos, existência de outro imóvel, oposição ou interrupção da posse).

Pois bem. Sendo a usucapião coletiva um direito acidentalmente coletivo, sua declaração será possível por meio da tutela judicial coletiva (ações coletivas)? E, nesse sentido, caberia ação civil pública como uma ação de usucapião coletiva?

A ação civil pública, cujo regime jurídico é prescrito pela Lei no. 7.347/1985 (Lei da Ação Civil Pública), apresenta-se no Brasil como o meio processual típico para a tutela dos direitos coletivos, especialmente naquelas situações em que se discutem direitos indivisíveis e de titulares indeterminados.

Por esses motivos, Ibraim José das Mercês Rocha (2001, online) a resposta àquela pergunta é positiva. Entende que o desenvolvimento urbano e o direito à moradia são direitos metaindividuais (difuso, coletivo ou individual homogêneo): 
Evidente que facilitar ou diminuir a possibilidade de legitimidade extraordinária está no âmbito de discricionariedade de legislador, mas considerando a natureza destes interesses, notadamente sociais, bem como o flagrante interesse que teria a administração pública em ajuizar este tipo de ação, em áreas de ocupação consolidada, retirando-lhe o pesado ônus de eventualmente se ver obrigada a desapropriar áreas para regularização de assentamentos urbanos, ou difusão de instrumentos e equipamentos sociais, poderia o legislador ter deferido um espectro de legitimidade mais ampla, legitimando entes da administração pública e o Ministério Público.

Contudo, a Lei da Ação Civil Pública não parece ser o meio processual adequado para a declaração da prescrição aquisitiva plúrima. Primeiro porque ela é voltada para a tutela de direitos difusos (e a usucapião plúrima é direito coletivo stricto sensu); e segundo porque a sentença de usucapião (independentemente de sua modalidade) sempre terá como conteúdo prevalecente o declaratório de um direito ou interesse. E em nenhum dispositivo da Lei no. 7.347/1985 a declaração de um direito aparece como objeto de tutela. Veja, como exemplo:

Art. 1ำ Regem-se pelas disposições desta Lei, sem prejuízo da ação popular, as ações de responsabilidade por danos morais e patrimoniais causados:

$[\ldots]$;

IV - a qualquer outro interesse difuso ou coletivo.

Art. 3으 A ação civil poderá ter por objeto a condenação em dinheiro ou o cumprimento de obrigação de fazer ou não fazer.

Quanto ao art. 1으, observe que se limita a ação civil pública àqueles casos de "responsabilidade por danos morais e patrimoniais causados", cujo conteúdo da decisão judicial será condenatório. De igual maneira, o art. 3o é bem claro que poderá ter a ação um propósito condenatório. Na realidade, porém, essa restrição não parece existir na prática, já que é muito comum o Ministério Público propor ação civil pública para, por exemplo, condenar o Estado a fornecer medicamento para um indivíduo especifico, o que não é responsabilidade civil, por óbvio. Os tribunais parecem aceitar um espectro muito mais amplo para essa ação coletiva. Aliás, tomando por base o art. 83 do Código de Defesa do Consumidor, entende-se existir no ordenamento jurídico brasileiro uma atipicidade da tutela coletiva, no sentido de que poderia ser proposta qualquer ação (DIDIER JUNIOR; ZANETI JR., 2018, p. 114).

Por isso, não há, prima facie, respaldo legal para se considerar a declaração de usucapibilidade coletiva por meio de ação civil pública, apesar de vantagens que poderia trazer aos usucapientes pelas especialidades e simplificações do seu procedimento.

A ação de usucapião especial urbana coletiva pode ser uma ação civil coletiva, ou uma ação ordinária, comum, constituída por um polo ativo plúrimo (litisconsórcio). E isso restou mais claro com a Lei no. 13.465/2017, que trouxe a figura de um condomínio especial.

Para a declaração de usucapião, verifica-se a possibilidade de propositura de dois tipos de ações: 1) a ação civil coletiva, disciplinada pelo microssistema da tutela coletiva, que possui regras 
comunicáveis e é composto pelo Código de Defesa do Consumidor, pela Lei da Ação Popular, pela Lei da Ação Civil Pública, pela Lei de Improbidade Administrativa, pelo Código de Processo Civil dentre outras normas; e 2) a ação (ordinária) de usucapião especial coletiva urbana, litisconsorciada no polo ativo.

Humberto Theodoro Júnior e Juliana Cordeiro de Faria (2014, p. 10) demonstram que, em caso de direitos individuais homogêneos, o ordenamento jurídico brasileiro harmonizou um sistema de legitimação ordinária clássica e de legitimação extraordinária para a tutela de tal classe de direitos:

[...] em se tratando de direitos individuais homogêneos, ao lado da ação individual, o legislador, por razões políticas, autorizou paralelamente o manejo da ação coletiva, por meio da técnica clássica de substituição processual, contemplando os legitimados ope legis extraordinários para sua defesa. Ou seja, para os direitos individuais homogêneos, convive a técnica de defesa individual tradicional com aquela coletiva, pelo regime da substituição processual. Os legitimados ativos, em nome próprio, defendem direitos individuais alheios, cujos titulares poderiam valer-se de ações individuais, se as preferissem, como revela textualmente o art. 91 do CDC.

Trata-se, portanto, de legitimação extraordinária, aquela conferida aos legitimados do art. 82 do CDC para a defesa dos direitos individuais homogêneos, uma vez que em nome próprio buscam a tutela de direitos alheios, isto é, dos indivíduos.

Com efeito, na sistemática de tutela dos direitos individuais homogêneos, convivem a legitimação ordinária clássica dos titulares individuais do direito e a legitimação extraordinária clássica, i.e., a substituição processual autorizada por lei a que alude o art. 6 o do CPC. A tutela coletiva dos direitos individuais homogêneos é, assim, alcançada por meio do instrumento processual clássico da substituição processual. O que se deseja aqui é autorizar a substituição dos verdadeiros titulares do direito pelos legitimados extraordinários como meio de alcançar uma eficiente tutela dos próprios direitos individuais que, pelo fato de serem inseridos em um microssistema de processo coletivo, não perdem a sua essência de direitos subjetivos individuais.

É certo que a previsão de ação coletiva na espécie não anula a possibilidade de o indivíduo preferir o exercício da ação individual, nem impede que a solução da demanda possa ser diferente para algum interessado figurante do grupo. Justamente porque, na raiz, os direitos congregados são individuais e podem, caso a caso, sofrer reflexos de circunstâncias pessoais.

Para se bem compreender a estrutura da tutela jurisdicional coletiva dos direitos individuais homogêneos, é preciso ter em mente que se trata de "derechos individuales y divisibiles, típicos derechos subjetivos tradicionales, pertenecientes a titulares exclusivos, que admiten tratamiento general y colectivizado no por su naturaleza, sino a partir de su homogeneidad, por construcción legislativa".

É preciso, contudo, observar que as usucapiões especiais urbanas possuem normas procedimentais específicas. Por isso, o meio processual adequado à tutela da usucapião plúrima deve obedecer ao procedimento especial fixado nos $\S \S 20$ e 30 do art. 10 e nos arts. 11 a 14, todos da Lei no. 10.257/2001 (Estatuto das Cidades). 
Observe, contudo, que as normas processuais desse dispositivo não são suficientes para a prática dos atos processuais inerentes à ação de usucapião coletiva. O art. 14 resolve essa insuficiência mandando aplicar o procedimento sumário do antigo Código de Processo Civil de 1973. Veja que sequer mandava utilizar as normas do procedimento especial para a usucapião de terras particulares (arts. 941 a 945 do CPC/1973), que não foram repetidas pelo CPC/2015.

O procedimento sumário não mais existe no CPC/2015. Daí, questiona-se, como fica a remição do art. 14 ao CPC.

O parágrafo único do art. 1.049 do CPC/2015 resolve a questão: toda vez que uma lei se referir à aplicação do antigo procedimento sumário, deverão ser aplicadas as normas do procedimento comum do atual Codex:

Art. 1.049. Sempre que a lei remeter a procedimento previsto na lei processual sem especificá-lo, será observado o procedimento comum previsto neste Código.

Parágrafo único. Na hipótese de a lei remeter ao procedimento sumário, será observado o procedimento comum previsto neste Código, com as modificações previstas na própria lei especial, se houver.

Portanto, a ação de usucapião coletiva terá o seguinte regime jurídico:

1. Regras principais: $\S \S 20$ e 30 do art. 10 e arts. 11 a 14 do Estatuto das Cidades;

2. Regras subsidiárias: as do microssistema da tutela coletiva, que possui regras comunicáveis e é composto pelo Código de Defesa do Consumidor (arts. 81 a 104), pela Lei da Ação Civil Pública, pela Lei da Ação Popular, pela Lei de Improbidade Administrativa, dentre outras leis; e

3. Regras supletivas: as do procedimento comum do Código de Processo Civil de 2015 (arts. 318 e seguintes c/c parágrafo único do art. 1.049).

Contudo, feita uma pesquisa de julgados do Supremo Tribunal Federal, do Superior Tribunal de Justiça e de Tribunais de Justiça dos Estados, constatou-se que em 96\% dos julgados a usucapião coletiva foi discutida em uma ação que não tinha o caráter de ação civil coletiva. Ou seja, embora se esteja diante de um direito acidentalmente coletivo, na prática, a tutela da usucapião tem sido feita pela via ordinária, com os possuidores interessados constituindo polo ativo em litisconsórcio.

A metodologia empregada na pesquisa dos julgados foi a seguinte:

\begin{tabular}{|l|l|}
\hline Sítio eletrônico & http://www.stj.jus.br/SCON/pesquisar.jsp \\
\hline Data & $01 / 08 / 2018$ \\
\hline Termos de busca & 1) “usucapião coletiva defensoria publica"; \\
& 2) “ação coletiva de usucapião"; e \\
\hline
\end{tabular}




\begin{tabular}{|l|l|}
\hline Espécies de julgados selecionados & 3) “usucapião processo coletivo" \\
\hline Total de julgados encontrados & 45 \\
\hline $\begin{array}{l}\text { Julgados que diziam respeito àos e decisões monocráticas } \\
\text { matéria }\end{array}$ & 21 \\
\hline Método de análise & qualiquantitativo \\
\hline Conclusão & $\begin{array}{l}\text { 1) pela estatística, em 96\% dos julgados a usucapião coletiva } \\
\text { foi discutida em uma ação de usucapião coletiva que não } \\
\text { tinha o caráter de ação civil coletiva; } \\
\text { 2) chamou a atenção o fato de que não se encontrou nenhum } \\
\text { julgado que tivesse na origem, no piso, uma ação coletiva } \\
\text { proposta por Defensoria Pública. }\end{array}$ \\
\hline
\end{tabular}

Apenas como exemplo, cite-se o julgado do Supremo Tribunal Federal na Medida Cautelar

na Ação Cautelar no. 3.804/RS, Rel. Min. Luís Roberto Barroso, j. em 25/02/2015:

AÇÃO CAUTELAR. Pretensão de conferir efeito suspensivo a recurso extraordinário inadmitido na origem. 1. Medida proposta por associação que não comprovou ter recebido poderes de representação, nos termos do art. 5o, XXI, da Constituição. [...]. DECISÃO: 1. Trata-se de ação cautelar, com pedido de medida liminar, que objetiva conferir efeito suspensivo a recurso extraordinário inadmitido pelo Tribunal de Justiça do Rio Grande do Sul (TJ/RS). 2. A lide de origem diz respeito à posse de terreno localizado na Rodovia Frederico Dihl, no 1920, no Município de Alvora (RS). Foram propostas cinco ações judiciais para tratar do tema: duas ações de reintegração de posse, pelos ora réus da medida cautelar; duas ações de manutenção de posse; e uma ação de usucapião especial coletivo, com 67 autores. 3. Examinando os feitos, as instâncias ordinárias concluíram, liminarmente, pela manutenção da posse de parte do terreno por alguns de seus ocupantes e pela reintegração da parcela restante aos proprietários. Assinalou-se que, excetuados os poucos ocupantes que comprovaram exercer posse justa há mais de ano e dia, os demais não teriam demonstrado direito a permanecer no bem. Ao contrário, os elementos constantes dos autos denotariam que houve, por eles, esbulho recente da propriedade. [...]. 6. Em paralelo, o juízo de primeiro grau determinou, em 19.02.2015, a efetivação da reintegração de posse, após sucessivas remarcações. Frisou que a reintegração não deve atingir a posse de determinados ocupantes, quanto a parcelas especificadas do imóvel, uma vez que quanto a eles houve reconhecimento de posse justa há mais de ano e dia. 7. Diante da iminência da execução da medida reintegratória, marcada para 26.02.2015, foi ajuizada a cautelar em foco, visando ao conhecimento do recurso extraordinário e à concessão, a ele, de efeitos suspensivos. A cautelar foi proposta pela Associação Comunitária Alto da Colina e, basicamente, reproduz os argumentos indicados no próprio recurso que se pretende fazer conhecer. 8. É o relatório. Decido. 9. A Associação Comunitária Alto da Colina não goza de legitimidade para postular a cautelar, uma vez que não comprovou ter recebido poderes de representação dos autores da ação de usucapião coletivo, partes recorrentes do RE que se pretende destrancar e ao 
qual se requer a conferência de efeito suspensivo. 10. Com efeito, nos termos do art. 5ㅇ, XXI, da Constituição, as associações civis somente podem representar seus filiados em juízo quando expressamente autorizadas (RE 573232, Rel. Min. Marco Aurélio; 192302, Rel. Min. Marco Aurélio; MS 23879, Rel. Min. Maurício Corrêa; RE 225965, Rel. Min. Carlos Velloso, dentre outros). 11. No presente caso, não foi anexado aos autos sequer o estatuto social da Associação autora. Juntaram-se, apenas, a procuração da própria Associação para os advogados que patrocinam a causa e documentos relativos aos processos de origem. 12. Há de se notar que todos os atos processuais praticados até o ajuizamento da presente cautelar se deram pelos próprios ocupantes do terreno, não havendo notícia da atuação da mencionada associação nas instâncias inferiores nem mesmo como assistente processual. [...]. 17. Diante do exposto, nos termos dos precedentes citados, nego seguimento à presente ação cautelar inominada (RI/STF, art. 21, §1으), ficando prejudicado o exame do pedido de medida liminar. Arquivem-se os autos.

É preciso ter em mente que a ação civil coletiva tem um rol de legitimados ativos mais restrito. Seriam aqueles previstos no caput do art. 82 do Código de Defesa do Consumidor e no caput do art. 5ㅇda Lei da Ação Civil Pública:

\begin{tabular}{|c|c|}
\hline $\begin{array}{lll}\text { Lei } & \text { no. } & 7.347 / 1985 \\
\text { (Lei da } & \text { Ação } & \text { Civil } \\
\text { Pública) } & & \end{array}$ & $\begin{array}{l}\text { Art. 5o. Têm legitimidade para propor a ação principal e a ação cautelar: } \\
\text { I - o Ministério Público; } \\
\text { II - a Defensoria Pública; } \\
\text { III - a União, os Estados, o Distrito Federal e os Municípios; } \\
\text { IV - a autarquia, empresa pública, fundação ou sociedade de economia mista; } \\
\text { V - a associação que, concomitantemente: } \\
\text { a) esteja constituída há pelo menos } 1 \text { (um) ano nos termos da lei civil; } \\
\text { b) inclua, entre suas finalidades institucionais, a proteção ao patrimônio } \\
\text { público e social, ao meio ambiente, ao consumidor, à ordem econômica, à } \\
\text { livre concorrência, aos direitos de grupos raciais, étnicos ou religiosos ou ao } \\
\text { patrimônio artístico, estético, histórico, turístico e paisagístico. }\end{array}$ \\
\hline $\begin{array}{l}\text { Lei no. 8.078/1990 } \\
\text { (Código de Defesa do } \\
\text { Consumidor) }\end{array}$ & $\begin{array}{l}\text { Art. 82. Para os fins do art. 81, parágrafo único, são legitimados } \\
\text { concorrentemente: } \\
\text { I-o Ministério Público, } \\
\text { II-a União, os Estados, os Municípios e o Distrito Federal; } \\
\text { III - as entidades e órgãos da Administração Pública, direta ou indireta, ainda } \\
\text { que sem personalidade jurídica, especificamente destinados à defesa dos } \\
\text { interesses e direitos protegidos por este código; } \\
\text { IV - as associações legalmente constituídas há pelo menos um ano e que } \\
\text { incluam entre seus fins institucionais a defesa dos interesses e direitos } \\
\text { protegidos por este código, dispensada a autorização assemblear. }\end{array}$ \\
\hline
\end{tabular}


Mas, e se não houver uma associação de moradores do núcleo urbano informal? E se aqueles órgãos de defesa dos interesses coletivos não atuarem no caso? Aí, então, se justifica a propositura de uma ação ordinária de usucapião coletiva, manejada pelos possuidores em grupo.

Os incisos I a III do caput do art. 12 do Estatuto das Cidades estipula a quem pertence a legitimidade ativa para a propositura da ação de usucapião especial (individual e coletiva), quais sejam, especificamente para o caso da plúrima: 1) os próprios possuidores de uma composse, litisconsorciados (inciso I e II); e 2) uma associação de moradores da comunidade, com personalidade jurídica (inciso III).

O núcleo urbano informal é uma situação fática, isto é, um conjunto edificado ocupado por várias pessoas. Não é a comunidade ou o conjunto de moradores em si. Por isso, não se pode considerar o núcleo urbano informal um ente despersonalizado com capacidade processual especial para estar em juízo, o que poderia, se fosse o caso, encontrar fundamento no inciso IX do art. 75 do CPC/2015: “Art. 75. Serão representados em juízo, ativa e passivamente: [...]. IX - a sociedade e a associação irregulares e outros entes organizados sem personalidade jurídica, pela pessoa a quem couber a administração de seus bens; [...]".

O legitimado ativo poderá ser uma associação de moradores do núcleo urbano informal, desde que:

1) seja uma pessoa jurídica (ente personalizado); e

2) haja previsão estatutária para a pessoa jurídica agir em juízo em nome dos associados.

Mas, pelo fato de a usucapião coletiva ser um direito individual homogêneo, os próprios compossuidores têm legitimidade ativa. Mas, nesse caso, estão autorizados a pleitear tão somente se litisconsorciados. É que a hipótese do inciso I somente diz respeito à usucapião especial individual. Se pleiteada individualmente, admitir-se-ia alguém pleitear por direito de outrem, o que não é permitido pelo caput do art. 18 do Código de Processo Civil (2015): “Art. 18. Ninguém poderá pleitear direito alheio em nome próprio, salvo quando autorizado pelo ordenamento jurídico. [...]".

Se for constituído um litisconsórcio ativo, este será multitudinário e unitário, conforme previsto no CPC/2015: “Art. 116. O litisconsórcio será unitário quando, pela natureza da relação jurídica, o juiz tiver de decidir o mérito de modo uniforme para todos os litisconsortes".

Reforça, ainda, a tese da unitariedade, o art. 117 do CPC e o fato de que os possuidores não constituirão relação distinta (especial) com o proprietário usucapido, já que a usucapião ocorre coletivamente, em prol de um todo unido: "Art. 117. Os litisconsortes serão considerados, em suas relações com a parte adversa, como litigantes distintos, exceto no litisconsórcio unitário, caso em que os atos e as omissões de um não prejudicarão os outros, mas os poderão beneficiar".

Sobre a necessariedade ou a facultatividade desse litisconsórcio, há divergências. 
Para José Carlos de Moraes Salles (2010, pp. 333 e segs.), em razão dos propósitos dessa modalidade de usucapião, não há que se falar de necessariedade. Trata-se, portanto, de um litisconsórcio facultativo:

Muito embora seja recomendável que a propositura da ação de usucapião especial urbana coletiva seja feita, em litisconsórcio, por todos os possuidores de área nas condições previstas no art. 10 do Estatuto da Cidade, esse litisconsórcio será facultativo e não necessário. Não percamos de vista que nem sempre será possível obter a anuência de centenas ou de talvez milhares de possuidores para a propositura dessa ação em litisconsórcio, sendo lícito a um único interessado intentar a referida ação, decorrendo essa legitimação do disposto na primeira parte do inc. I do art. 12, ou seja, da expressão "o possuidor, isoladamente.

Por outro lado, Celso Augusto Coccaro Filho (2004, online) sustenta tratar-se de caso de

litisconsórcio unitário necessário, com base nos seguintes fundamentos:

Não incluímos a hipótese prevista no inc. I do mesmo artigo ("o possuidor, isoladamente ou em litisconsórcio originário ou superveniente") que, a toda evidência, diz respeito ao usucapião individual. A lei não prevê, de forma expressa, a substituição processual da coletividade por um possuidor isolado, o que é exigido pelo art. 6.o do Código de Processo Civil [1973].

A aplicação subsidiária das normas relativas aos direitos metaindividuais não ampara a legitimidade do possuidor, de forma isolada, ainda que demonstre integrar a coletividade e deter as características do grupo de modo a representá-lo, solução prevista na class action do Direito norte-americano, sem correlato na legislação brasileira.

A menção aos "possuidores, em estado de composse", do inc. II, também confronta o litisconsórcio mencionado no inc. I, que é facultativo e não unitário (no pólo processual ativo).

O inc. II do art. 12, ao prever a legitimidade dos "possuidores, em estado de composse", leva a crer que há litisconsórcio necessário e unitário, decorrente do estado de indivisão e concomitância de direitos que qualifica a figura jurídica. Todos os integrantes da comunidade, aptos a se beneficiar da sentença, deverão integrar o pólo processual ativo, apresentando-se como compossuidores. O estado de composse deverá, evidentemente, ser demonstrado, e, também de forma evidente, tal prova não é documental. É de se indagar se o dispositivo chega a admitir a "composse", dotada de capacidade processual e representada por administrador. A redação desmente a palpitante possibilidade, ao se referir em primeiro lugar aos possuidores em situação de fato de composse.

Alexandre Freitas Câmara (2002, pp. 45-46), no entanto, entende que a demanda pode ser proposta por um possuidor, individualmente. Defende que os incisos I e II do art. 12 são casos de legitimação ordinária e que cada possuidor pode agir como substituto processual de todos os demais:

Quando um (ou alguns) dos possuidores demandar sozinho, o demandante estará em juízo não só na qualidade de legitimado ordinário, mas também como legitimado extraordinário, atuando como substituto processual dos possuidores que não estiverem em juízo (já que a sentença de procedência, 
neste caso, reconhecerá não só a existência do direito do demandante, mas também dos outros possuidores que não forem parte da demanda).

Ainda de acordo com Alexandre Freitas Câmara (2002, pp. 45-46), o litisconsórcio será facultativo e simples, por dois motivos: 1ํ) o ingresso na via judicial depende da vontade da pessoa que exerce posse no núcleo urbano informal; e 2ํㅡ) há a possibilidade de decisões diferentes (por exemplo, não irá usucapir nessa modalidade o possuidor que for proprietário de outro imóvel):

No caso da demanda de declaração de usucapião urbano coletivo, a legitimidade ativa é, ordinariamente, daqueles que comparecerem em juízo afirmando sua condição de possuidores que tenham adquirido a propriedade urbana através do usucapião coletivo. Cada possuidor pode demandar isoladamente, sendo ainda possível a formação de um litisconsórcio ativo, o qual será facultativo e simples. Facultativo, pois a formação do litisconsórcio dependerá da vontade de quem ajuíza a demanda. Simples, pois é perfeitamente possível conceber que algum dos litisconsortes ativos não preencha os requisitos para aquisição da propriedade, caso em que será julgada improcedente a demanda de reconhecimento de seu direito individual (ou seja, na sentença ficará acertado que esse litisconsorte não adquiriu fração ideal do terreno).

Apesar dos fundamentos bastante racionais das ideias anteriores, o litisconsórcio ativo da usucapião especial coletiva deve ser necessário. O caput do art. 10 do Estatuto das Cidades prescreve que os núcleos urbanos informais são suscetíveis de serem usucapidos coletivamente. Ou seja, é o grupo que usucape o núcleo; logo, será de todos. Outrossim, o § 3ㅇ do art. 10 estabelece que na sentença o juiz atribuirá igual fração ideal de terreno a cada possuidor, independentemente da dimensão do terreno que cada um ocupe, indicando a unidade de decisão e de atuação de todos os possuidores envolvidos.

Mas, e como resolver o possível problema de integração litisconsorcial se houver usucapiente renitente em integrar o polo ativo?

Para resolver esse problema, tome-se como referência o estudo de Gilberto Notário Ligero e Luiz Fernando Belinetti (2005, pp. 155-182), com as adaptações necessárias às circunstâncias da usucapião coletiva.

Fixando o problema, a renitência ocorre quando um dos possuidores integrantes do núcleo informal urbano, suscitando sua liberdade, se nega a integrar o polo ativo da ação de usucapião. De outro lado, ficará prejudicado o acesso à justiça dos outros possuidores que querem ver declarado seu direito de copropriedade sobre o núcleo urbano informal. Ao prejuízo que essa resistência causa, aqueles autores chamam de litigiosidade contida.

A pesquisa de Gilberto Notário Ligero e Luiz Fernando Belinetti (2005, pp. 160-162) indicou existirem na literatura jurídica brasileira duas teses sobre a integralização obrigatória do litisconsórcio necessário, as quais podem ser sistematizadas da seguinte maneira: 


\begin{tabular}{|c|c|c|}
\hline Tese & Autores & Fundamentos \\
\hline Negativista & $\begin{array}{l}\text { Celso Agrícola Barbi, Cândido } \\
\text { Rangel Dinamarco, Humberto } \\
\text { Theodoro Junior, José } \\
\text { Raimundo Gomes da Cruz }\end{array}$ & $\begin{array}{l}\text { 1) A própria lei também descreverá o mecanismo a } \\
\text { ser utilizado para a formação do litisconsórcio, pois } \\
\text { os casos de necessariedade são raros e excepcionais; } \\
\text { 2) Geralmente, a lei dá legitimidade para cada um } \\
\text { dos litisconsortes (ex.: art. } 1.314 \text { do Código Civil); } \\
\text { 3) Haverá extensão subjetiva da coisa julgada para os } \\
\text { litisconsortes que não compuseram a relação } \\
\text { processual; } \\
\text { 4) Se a lei não traz a solução para a integração, então } \\
\text { o processo deve ser extinto sem julgamento do } \\
\text { mérito, por ilegitimidade da parte; } \\
\text { 5) A iniciativa das partes para demandar é um dogma } \\
\text { inquebrantável; } \\
\text { 6) Citação é um ato processual exclusivo para } \\
\text { chamar a juízo tão somente aquele que assumirá o } \\
\text { papel de demandado (réu). }\end{array}$ \\
\hline Afirmativista & $\begin{array}{l}\text { Homero Freire, José Manoel } \\
\text { de Arruda Alvim Neto, } \\
\text { Mathias Lambauer, José } \\
\text { Miguel Garcia Medina, Nelson } \\
\text { Nery Júnior, Alexandre Freitas } \\
\text { Câmara, José Roberto dos } \\
\text { Santos Bedaque, Thereza } \\
\text { Alvim, Cássio Scarpinella } \\
\text { Bueno, Marcelo Abelha } \\
\text { Rodrigues. }\end{array}$ & $\begin{array}{l}\text { 1) Pelo princípio constitucional do acesso à justiça, } \\
\text { não se admite suprimir a propositura da demanda } \\
\text { por aquele que pretenda acionar o Judiciário porque } \\
\text { o co-titular se recusa a litigar; } \\
\text { 2) O princípio dispositivo deve ser analisado em } \\
\text { conformidade com a garantia da ação; } \\
\text { 3) O co-titular que não queira litigar deverá ser } \\
\text { integrado à relação jurídico-processual mediante a } \\
\text { citação; } \\
\text { 4) Com a integração do obstinado, resolvido estará o } \\
\text { problema, de maneira que a sentença de mérito seja } \\
\text { utiliter. }\end{array}$ \\
\hline
\end{tabular}

Segundo os afirmativistas, a integralização involuntária do polo ativo se dará por meio da citação do litisconsorte ativo renitente, a pedido do autor ou ex officio. Sim, parece anacrônico, mas a citação seria o ato processual para trazer um autor à composição da relação jurídica processual.

Gilberto Notário Ligero e Luiz Fernando Belinetti (2005, pp. 160-162) apresentam os argumentos de Homero Freire e Thereza Alvim, fundamentados em dispositivos do Código de Processo Civil de 1973:

A tese afirmativista na doutrina nacional teve, como precursor, Homero Freire, que, em 1954, escreveu dissertação sobre o tema, em que defendia a possibilidade de integração do litisconsorte ativo à relação processual. A solução encontrada pelo mencionado processualista, para a formação do litisconsórcio necessário ativo, é a determinação da citação de ofício. Atualmente, não há previsão legal que autorize a citação ex officio, ou seja, o juiz deverá ordenar ao autor que tome as providências para a promoção da citação do litisconsorte, nos termos do parágrafo único do artigo 47 do Código 
de Processo Civil de 1.973, sob pena de extinção do processo, sem julgamento do mérito. Thereza Alvim também defende a idéia de que a necessariedade litisconsorcial é uma realidade que abrange tanto o pólo passivo quanto o ativo; e diz que uma pessoa que pretenda provocar o Judiciário, em busca de uma solução para a lesão ou ameaça a um direito subjetivo, não pode ter essa garantia de provocação tolhida, porque o co-titular do mesmo direito não tem nenhum interesse em demandar.

A solução encontrada pela processualista surge, a partir de uma compreensão diferenciada do fenômeno da citação, E comenta: "Citação, aqui, só pode ser entendida como forma de integração do processo, que se faz essencial, por força de lei. Portanto, apesar da definição do art. 213, do Código de Processo Civil, citação tornou-se palavra equívoca, porém, sempre importando em integração da relação processual, que enseja a fidelidade ao princípio da bilateralidade de audiência, do contraditório".

Assim sendo, a presença de todos os litisconsortes na relação processual, quando se trata de litisconsórcio necessário, é conditio sine qua non para uma sentença utiliter, ou seja, sentença que, eficazmente, produza seus efeitos.

A dificuldade de compreender a citação como um ato amplo para além da integralização do polo passivo da relação jurídica processual, decorria da definição de citação adotada pelo art. 213 do CPC/1973: "Art. 213. Citação é o ato pelo qual se chama a juízo o réu ou o interessado a fim de se defender".

O art. 238 do Código de Processo Civil de 2015, no entanto, amplia a função e o significado de citação: "Art. 238. Citação é o ato pelo qual são convocados o réu, o executado ou o interessado para integrar a relação processual".

Enquanto no CPC/1973 a citação era utilizada para a apresentação da defesa, no CPC/2015 a citação é um ato para o réu e qualquer outro interessado integrarem o processo e ocuparem o polo da relação jurídica.

Junte-se a isso, como outro argumento, o art. 114 do CPC/2015, que assim define o litisconsórcio necessário: "Art. 114. O litisconsórcio será necessário por disposição de lei ou quando, pela natureza da relação jurídica controvertida, a eficácia da sentença depender da citação de todos que devam ser litisconsortes".

Observe que o dispositivo fala em citação de todos que devam ser litisconsortes, sem especificar se ativos ou passivos.

Se o autor litisconsorte integrado involuntariamente ao processo for desidioso, isso não prejudicará os demais interessados. Ele, inclusive, se beneficiará com os efeitos da sentença de usucapião. O direito dos demais autores, a regularização urbana e a urbanização do núcleo informal restarão garantidos.

Por fim, há outra possibilidade: um dos autores não integrou o polo ativo por ter sido excluído pelos demais, maliciosamente ou não. Ou, então, o preterido desconhece a propositura da ação. Ainda, é possível ter havido a falta de citação do referido autor. 
Nesses casos, a decisão será nula, nos termos do inciso I do caput do art. 115 do CPC/2015: "Art. 115. A sentença de mérito, quando proferida sem a integração do contraditório, será: I - nula, se a decisão deveria ser uniforme em relação a todos que deveriam ter integrado o processo; [...]". Deverá o prejudicado, assim, propor a actio nullitatis (querela nullitatis insanabilis), que é a ação declaratória de nulidade da sentença judicial da ação de usucapião coletiva.

Os autores da ação de usucapião poderão requerer os benefícios da justiça e da assistência judiciária gratuita, conforme $\S 2$ o do art. 12 da Lei ํo. 10.257/2001. Tal assistência é deferida conforme os pressupostos da Lei no. 1.060/1950, ou seja, somente aos necessitados (art. 1으). Entenda-se por necessitados os pobres, que na forma da lei são aqueles que declaram não poder arcar com as custas, despesas processuais e honorários de advogado sem prejuízo de seu sustento e de sua família.

Antes da nova redação do art. 10 do Estatuto das Cidades, a assistência gratuita era essencial porque o pressuposto subjetivo dos usucapientes eram constituir população de baixa renda, ou seja, pessoas pobres economicamente.

Com a nova redação do art. 10 dada pela Lei no. 13.465/2017, a pobreza deixou de ser um critério de deferimento dessa usucapião especial. Portanto, é possível que no meio do grupo de pessoas que constituem o núcleo urbano individual haja sujeitos que não fazem jus aos benefícios da justiça e da assistência judiciária gratuita.

Dessa maneira, é possível que a assistência seja deferida para uns e indeferida para outros; ou, ainda, que alguns autores sejam beneficiados e outros sequer requeiram.

A propósito, a Defensoria Pública tem legitimidade para agir na tutela dos direitos dos necessitados, podendo representar os usucapientes (ou alguns deles), conforme o art. 185 do CPC/2015: “Art. 185. A Defensoria Pública exercerá a orientação jurídica, a promoção dos direitos humanos e a defesa dos direitos individuais e coletivos dos necessitados, em todos os graus, de forma integral e gratuita".

Ainda sobre a atuação de outros órgãos na ação, o § 1ㅇ do art. 12 da Lei no. 10.257/2001 (c/c art. 176 do CPC/2015) obriga que o Ministério Público intervenha no pleito como custos legis.

Quanto à atuação do Ministério Público, Ibraim José das Mercês Rocha (2001, online) vai além e entende que o órgão tem legitimidade ativa ad causam para a propositura de ação coletiva visando à declaração de usucapião coletiva:

Observamos que na ação de usucapião coletivo o legislador restringiu de forma muito peculiar os critérios objetivos de aferição da legitimidade do substituto processual, diferentemente do que fez no caso de outro instrumento de tutela coletiva, que é a ação civil pública, onde o sistema inseriu uma legitimidade do tipo concorrente e disjuntiva, prevista no artigo 
$5^{\circ}$ da Lei 7.347/85, com as ampliações da Lei 8.078/90, deferida que foi ao Ministério Público, órgãos da Administração Pública, direta ou indireta, ainda que sem personalidade jurídica, desde que tenham por finalidade a defesa de interesses lesados, bem como as associações legalmente constituídas, velhas de um ano e com fins institucionais de defesa de interesses, permitindo, ainda a lei, que esta pré-constituição possa até ser dispensada pelo juiz, no caso da relevância do interesse social a ser tutelado, como previsto no $\S 1$ 으, do artigo 82 da Lei $n^{\circ} 8.078 / 90$.

Evidente que facilitar ou diminuir a possibilidade de legitimidade extraordinária está no âmbito de discricionariedade de legislador, mas considerando a natureza destes interesses, notadamente sociais, bem como o flagrante interesse que teria a administração pública em ajuizar este tipo de ação, em áreas de ocupação consolidada, retirando-lhe o pesado ônus de eventualmente se ver obrigada a desapropriar áreas para regularização de assentamentos urbanos, ou difusão de instrumentos e equipamentos sociais, poderia o legislador ter deferido um espectro de legitimidade mais ampla, legitimando entes da administração pública e o Ministério Público.

De fato, tem razão Ibraim José das Mercês Rocha, afinal, nesse caso específico da usucapião coletiva, é possível se fazerem presentes pessoas vulneráveis em processo de favelização, além do interesse social na regularização fundiária urbana e na garantia da moradia regular.

No polo passivo da ação deverá figurar o proprietário do imóvel urbano. Contudo, é preciso ter em mente que a usucapião coletiva se restringe aos núcleos urbanos informais, que são aqueles clandestinos, irregulares ou nos quais não foi possível realizar, por qualquer modo, a titulação de seus ocupantes, ainda que atendida a legislação vigente à época de sua implantação ou regularização (art. 11, II da Lei no. 13.465/2017).

Muito provavelmente, então, essa modalidade de usucapião terá lugar em imóveis que não têm matrícula junto ao Registro Geral de Imóveis, isto é, não estão "registrados". Disso decorrerá a impossibilidade de identificar um proprietário registral. Isso, claro, quando não se tratar de terras devolutas.

Por isso, no polo passivo, não necessariamente figurará o proprietário do imóvel, podendo ser o possuidor primitivo, que se apropriou, ocupou, o imóvel no passado, mas nunca teve a situação fática regularizada. Logo, é possível, então, que se tenha um réu indeterminável na ação de usucapião coletiva.

A propósito, sendo o núcleo urbano informal uma ocupação clandestina, pode ocorrer de o proprietário ou legítimo possuidor imóvel surgir e se insurgir contra o apossamento pela comunidade do núcleo. Nesse caso, o proprietário ou possuidor tem a seu favor a tutela interdital ou petitória, podendo propor a ação de reintegração de posse ou qualquer outra de natureza reipersecutória e petitória.

Em caso de propositura de ação possessória ou petitória em face dos ocupantes do núcleo urbano informal, admite-se a arguição de usucapião coletiva em contestação, como matéria de 
defesa. O Supremo Tribunal Federal desde 1963 admitia tal possibilidade por meio da Súmula №. 237: "O usucapião pode ser argüído em defesa" [sic]. Esse entendimento se consolidou na Lei no. 10.257/2001, que deu eficácia registral translativa à sentença da ação cuja usucapião coletiva fosse suscitada em contestação: "Art. 13. A usucapião especial de imóvel urbano poderá ser invocada como matéria de defesa, valendo a sentença que a reconhecer como título para registro no cartório de registro de imóveis". Veja, como exemplo, o Recurso Extraordinário com Agravo: ARE no․ 669.376/RS, Rel. Min. Cármen Lúcia, j. em 02/02/2012.

Nesse caso, volta à tona a questão da necessariedade de um polo passivo plúrimo, ou seja, se a defesa for a consolidação da usucapião coletiva, então todos os possuidores do núcleo urbano informal deverão, necessariamente, integrar a relação jurídica processual no polo passivo. Haverá, então, a formação de um litisconsórcio passivo unitário necessário.

Em tal hipótese, cabe ao autor providenciar a citação de todos os réus necessários, e, se não o fizer, o juiz poderá determiná-lo sob pena de extinção do processo, conforme prescreve o parágrafo único do art. 115 do CPC/2015: “Art. 115. [...]. Parágrafo único. Nos casos de litisconsórcio passivo necessário, o juiz determinará ao autor que requeira a citação de todos que devam ser litisconsortes, dentro do prazo que assinar, sob pena de extinção do processo".

Mas, por vezes, os réus que já foram citados têm interesse na continuidade do feito, para que seja declarada a prescrição aquisitiva em seu favor. Aí, o sistema oferece o mecanismo da intervenção iussu iudicis para que o juiz, ex officio, determine a participação dos outros sujeitos necessários à integração da relação jurídica. Esse litisconsórcio ulterior judicial está previsto expressamente naquele parágrafo único do art. 115 do CPC/2015.

Com a propositura da ação de usucapião coletiva, ou com sua alegação em contestação, ficam suspensas quaisquer outras ações possessórias e petitórias propostas sobre o imóvel usucapiendo, conforme art. 11 do Estatuto das Cidades.

O termo central da formulação normativa do art. 11 é "sobrestar". Sobrestamento, na técnica processual, significa a suspensão da tramitação do feito e da prática dos atos processuais; não significa impedir.

Dessa maneira, o art. 11 pode ser interpretado da seguinte maneira:

1. Se já existirem ações possessórias e petitórias propostas, a propositura da ação de usucapião coletiva irá sobrestar tais feitos, ou seja, suspender as ações, que deverão aguardar o julgamento da segunda ação (CÂMARA, 2002, p. 45); $e$ 
2. Se ainda não foram propostas ações possessórias e petitórias, a precedente propositura da ação de usucapião coletiva não irá impedir que aquelas sejam propostas. Contudo, serão sobrestadas até o deslinda da ação de usucapião.

Sobre os efeitos da sentença da usucapião especial urbana coletiva, é importante destacar, preliminarmente, que, assim como toda e qualquer modalidade de usucapio, a consequência primária da usucapião coletiva é atribuir a propriedade privada de um imóvel urbano a um grupo de possuidores. Com isso, garante-se a tais pessoas a consolidação do seu patrimônio econômico.

Por outro lado, a usucapião, quando declarada, dá aos usucapientes a segurança de permanência na posse do imóvel, já que o proprietário pro forma irá perder seu direito sobre a coisa.

Outrossim, é certo também que essa usucapião veio para proteger a integridade pessoal e, em sentido amplo, a dignidade da pessoa - dos sujeitos usucapientes, garantindo-lhes moradia. Nesse sentido, destaca Fábio Caldas Araújo (2015, p. 387): “A usucapião especial coletiva nasceu com o Estatuto da Cidade, Lei 10.257/2001, cujo principal objetivo foi o de implementar medidas de política urbana para o bem-estar da coletividade. A conversão de uma situação fática (posse) em título dominial (propriedade) promove autêntica inserção social".

E, com a Lei no. 13.465/2017, outra consequência foi mais destacada, qual seja, a regularização fundiária das habitações, especialmente daqueles núcleos constituídos de maneira irregular. A partir de 2017, as modalidades de usucapião foram equiparadas para fins de regularização fundiária, conforme se verifica do art. 15.

\section{A DECLARAÇÃO DE USUCAPIÃO COLETIVA PELA VIA ADMINISTRATIVA}

O art. 1.071 do Código de Processo Civil 2015 (Lei no. 13.105/2015) acrescentou no Capítulo III do Título V da Lei no 6.015/1973 (Lei de Registros Públicos) o art. 216-A. Esse dispositivo introduz no ordenamento jurídico uma nova forma de se obter a declaração de usucapião e, consequentemente, um título registrário para a regularização da transferência de domínio junto ao Registro Geral de Imóveis. Trata-se da usucapião extrajudicial. Assevera-se, contudo, que não se trata de uma nova modalidade de usucapião, mas de um outro procedimento para que o usucapiente tenha declarado seu domínio adquirido por meio da usucapião.

Mas, a Lei no. 13.465/2017 trouxe alterações ao novel dispositivo da Lei de Registros Públicos, esclarecendo pontos lacunosos e que dificultavam a operabilidade do novo procedimento.

Tanto na nova redação do art. 10 do Estatuto da Cidade, quanto na do art. 216-A da Lei de Registro Público, ambos reescritos pela Lei no. 13.465/2017, se verifica impedimentos para que 
ocorra a declaração da usucapião coletiva por tal via. De igual maneira, no Provimento no. 65/2017, do Conselho Nacional de Justiça, que estabelece diretrizes para o procedimento da usucapião extrajudicial nos serviços notariais e de registro de imóveis, não se encontra qualquer restrição nesse sentido.

Observe que em seu caput, o art. 216-A apenas prescreve que é admitido o pedido de reconhecimento extrajudicial de usucapião a requerimento do interessado, sem qualquer restrição de ordem subjetiva-ativa. A única exigência é que tal interessado deverá ser representado por profissional da advocacia. Aqui, a propósito, ganha especial papel a Defensoria Pública, como agente de regularização fundiária.

Mas, é importante destacar que o requerente, nesse caso, não pode ser cada uma das pessoas usucapientes, quer dizer, elas não podem requerer em nome próprio. A usucapião coletiva é declarada em favor de todos os possuidores que atendam aos requisitos legais da situação. Portanto, a representação por advogado ou pela Defensoria Pública é quanto ao grupo.

Não fosse assim, essa usucapião não seria coletiva, mas sim individual. Atento a isso, o legislador deixou claro no caput do art. 10 do Estatuto da Cidade que tais imóveis "são suscetíveis de serem usucapidos coletivamente".

Dessa maneira, tal qual ocorre na via judicial ordinária, aqui o requerimento administrativo deverá ser multitudinário, o equivalente ao litisconsórcio unitário-necessário. Por isso, a declaração pela cartorial parece que ocorrerá, somente, quando houver um acordo entre todos os possuidores.

Se o proprietário da área urbana não se manifestar no prazo de 15 dias, após notificação por escrito ou por edital, sua ausência de manifestação (silêncio) será interpretada como aceitação de perda do domínio, conforme preceitua o § 20 do art. 216-A.

A sistemática, incluindo procedimento e requisitos, é basicamente a mesma de quando o pleito é feito individualmente. Contudo, na hipótese de usucapião coletiva, o Oficial do Registro terá que analisar um requisito a mais, qual seja, verificar se os possuidores que compõem o núcleo urbano informal não são proprietários de outro imóvel urbano ou rural conforme exigido pelo caput do art. 10, in fine.

O Oficial tem poderes para tanto, pois para a elucidação de qualquer ponto de dúvida, poderá solicitar ou realizar diligências que se fizerem necessárias (§ 5ㅇ do art. 216-A), além de dispor do procedimento de dúvida (§ 70 do art. 216-A).

Inclusive, o Provimento no. 65/2017 do CNJ também prevê tais poderes extras ao Oficial, conforme se verifica nos seguintes dispositivos:

Art. 5‥ [...]. 
§ 10 O tabelião de notas poderá comparecer pessoalmente ao imóvel usucapiendo para realizar diligências necessárias à lavratura da ata notarial. [...].

Art. 17. Para a elucidação de quaisquer dúvidas, imprecisões ou incertezas, poderão ser solicitadas ou realizadas diligências pelo oficial de registro de imóveis ou por escrevente habilitado. [...].

$\S 2$ o Se, ao final das diligências, ainda persistirem dúvidas, imprecisões ou incertezas, bem como a ausência ou insuficiência de documentos, o oficial de registro de imóveis rejeitará o pedido mediante nota de devolução fundamentada. [...].

A pesquisa da existência de outro imóvel foi facilitada pela implantação do Sistema de Registro Eletrônico de Imóveis (SREI), criado pelo Provimento no. 47/2015 do Conselho Nacional de Justiça.

\section{DA FORMAÇÃO DE UM CONDOMÍNIO URBANO SIMPLES}

A Lei no. 13.465/2017 trouxe como novidade uma categorial condominial designada “Condomínio Urbano Simples”, com previsão nos arts. 61 a 63 (CUSTÓDIO, 2017, pp. 1930-1952).

A referida lei assim define a categoria:

Art. 61. Quando um mesmo imóvel contiver construções de casas ou cômodos, poderá ser instituído, inclusive para fins de Reurb, condomínio urbano simples, respeitados os parâmetros urbanísticos locais, e serão discriminadas, na matrícula, a parte do terreno ocupada pelas edificações, as partes de utilização exclusiva e as áreas que constituem passagem para as vias públicas ou para as unidades entre si.

Parágrafo único. O condomínio urbano simples será regido por esta Lei, aplicando-se, no que couber, o disposto na legislação civil, tal como os arts. 1.331 a 1.358 da Lei no 10.406, de 10 de janeiro de 2002 (Código Civil).

Para que fique caracterizado esse condomínio especial, as construções deverão atender aos seguintes requisitos:

1. Vários imóveis (casas ou cômodos) construídos sobre o mesmo prédio (terreno ou edificação);

2. Regularidade com o plano diretor urbano;

3. Partes de uso exclusivo pelo possuidor;

4. Partes de uso comum pelos possuidores;

5. Acesso à via pública ou acesso para as unidades entre si;

6. Averbação do uso das partes na matrícula do prédio.

Não cabe, contudo, considerar esse condomínio urbano simples como uma nova espécie de condomínio no Direito brasileiro, ao lado dos já conhecidos condomínios voluntário, necessário e 
edilício (arts. 1.314 a 1.358-A do Código Civil). Dessa maneira, o condomínio urbano simples nada mais é que uma forma de condomínio edilício (e não um tipo). Trata-se, na verdade, de uma denominação especial para um condomínio edilício que surge de forma especial, geralmente originado de invasões ou ocupações irregulares. São situações em que existem edilícios "informais" e que poderão passar por um processo de regularização mais simplificado (Reurb-S).

Essas colocações são necessárias para que se possa afirmar que a usucapião coletiva dá origem a um condomínio urbano simples: o conjunto de possuidores que constituem o núcleo urbano informal se torna, coletivamente, proprietários do condomínio urbano, o qual será instituído a partir do reconhecimento da usucapião coletiva.

Assim, a partir do título que reconhece a usucapião coletiva, proceder-se-á à instituição do condomínio, como prescrito no art. 62 da Lei no. 13.465/2017:

Art. 62. A instituição do condomínio urbano simples será registrada na matrícula do respectivo imóvel, na qual deverão ser identificadas as partes comuns ao nível do solo, as partes comuns internas à edificação, se houver, e as respectivas unidades autônomas, dispensada a apresentação de convenção de condomínio.

$\S 1$ 을 Após o registro da instituição do condomínio urbano simples, deverá ser aberta uma matrícula para cada unidade autônoma, à qual caberá, como parte inseparável, uma fração ideal do solo e das outras partes comuns, se houver, representada na forma de percentual.

$\S 2$ 을 unidades autônomas constituídas em matrícula própria poderão ser alienadas e gravadas livremente por seus titulares.

$\S 3$ 을 Nenhuma unidade autônoma poderá ser privada de acesso ao logradouro público.

§ 4ํ A gestão das partes comuns será feita de comum acordo entre os condôminos, podendo ser formalizada por meio de instrumento particular.

No regime jurídico anterior a 2017, a usucapião coletiva ocorria em áreas urbanas, ocupadas por população de baixa renda, onde não seria possível identificar os terrenos ocupados por cada possuidor. Todos os possuidores se tornariam proprietários de tudo.

Esse requisito foi retirado pela Reurb, com o propósito de simplificar a regularização das aglomerações habitacionais e comerciais informais.

Doravante, a usucapião coletiva se consolida com a instituição do condomínio urbano simples, que nada mais é que uma forma de condomínio edilício. Nesse caso, mantem-se como era anteriormente. Também não é novidade a possibilidade de instituição do condomínio, com a divisão ideal do todo, criando ou consolidando unidades autônomas internas com matrícula própria.

\section{CONCLUSÃO}


A usucapião especial urbana coletiva foi criada em 2001 pelo Estatuto da Cidade com o mesmo propósito primário de toda modalidade de usucapio: atribuir a propriedade privada àquele possuidor que dá à coisa - da qual não é proprietário - a utilização econômica e os fins a que se destina. Mas, obviamente, esse não é o único objetivo, visto que o Direito Urbanístico realiza outros elementos centrais que o orientam, a exemplo da função social da cidade e da propriedade.

Muito mais que isso, a usucapião coletiva é instrumento de política pública posto à disposição das instituições, para a regularização dos processos de favelização do Brasil afora.

A partir da Lei no. 13.465/2017 foram realizadas substanciais modificações nessa figura, que possibilitaram sua operabilidade e, principalmente, tornaram a usucapião coletiva um instrumento de regularização urbana para os processos de urbanização e atendimento da população. Embora não seja um benefício exclusivo de uma população de baixa renda, a modalidade segue - agora renovada - como um importante instrumento de melhoria das condições de vida daquelas pessoas submetidas ao processo de favelização do espaço urbano.

Nas reflexões epistemológicas preliminares, a pesquisa levantou como hipótese que a Lei noo. 13.465/2017 veio facilitar a declaração de usucapião coletiva com grandes impactos na sistemática anterior. O desenvolvimento da pesquisa revelou que os principais impactos foram nos requisitos subjetivos da usucapião coletiva e no procedimento de declaração da prescrição aquisitiva, uma vez que doravante é possível a usucapião pela via administrativa.

A usucapião coletiva segue sendo um direito transindividual; segue sendo um instrumento de realização patrimonial daqueles que nada ou pouco têm; e segue garantindo a propriedade e a moradia para a realização em comum da plena dignidade dos sujeitos de um núcleo urbano informal.

Essa pesquisa revelou, a partir do desenvolvimento de fundamentos jurídico-normativos e argumentos hermenêuticos sistemáticos, que a nova lei foi salutar e aperfeiçoou a operabilidade da usucapião coletiva, revigorando seu papel como elemento de regularização fundiária, atribuição de propriedade privada e concretização do direito fundamental de moradia.

Uma segunda fase da pesquisa já se encontra em desenvolvimento com o objetivo de refletir sobre a estatura desse instrumento de direito urbanístico, e sobre como essa normativa realiza os elementos centrais que orientam tal ramo do direito, a exemplo da função social da cidade e da propriedade.

\section{REFERÊNCIAS BIBLIOGRÁFICAS}


ABBOUD, Georges. Usucapião urbano coletivo e o art. 1.228 do Código Civil de 2002: novas perspectivas para a implementação da função social da propriedade urbana. In: Revista de Direito Privado, vol. 36, São Paulo, out. 2008.

ARAÚJO, Fábio Caldas. Usucapião. 3ạ ed. São Paulo: Malheiros, 2015.

BARBOSA MOREIRA, José Carlos. Tutela jurisdicional dos interesses coletivos ou difusos. In: Temas de direito processual. 3a série. São Paulo: Saraiva, 1984.

CÂMARA, Alexandre Freitas. Aspectos processuais do usucapião urbano coletivo. In: Revista da Esmese, Aracaju, n. 2, p. 41-52, 2002.

COCCARO FILHO, Celso Augusto. Usucapião especial de imóvel urbano: instrumento da política urbana. In: Jus Navigandi, Teresina, ano 8, n. 437, 17 set. 2004.

CUSTODIO, Vinícius Monte. Análise jurídica do loteamento de acesso controlado e do condomínio de lotes na Lei Federal no 13.465/2017. In: Revista Direito da Cidade. Vol. 9, n. 4, Rio de Janeiro, 2017, pp. 1930-1952.

DIDIER JUNIOR, Fredie; et al. Curso de Direito Processual Civil: Processo Coletivo. Vol. 4. 12a ed. Salvador: JusPodivm, 2018, p. 114.

FERRAZ, Sérgio. Usucapião especial (art. 9o a 14). In: DALLARI, Adilson Abreu; FERRAZ, Sérgio (Coords.). Estatuto da Cidade (Comentários à Lei Federal 10.257/2001). São Paulo: Malheiros, 2002. FICHTER, Joseph H. Definições para uso didático. In: FERNANDES, Florestan (Org.). Comunidade e Sociedade: leitura sobre problemas conceituais, metodológicos e de aplicação. São Paulo: Companhia Editora Nacional/EDUSP, 1973.

GRINOVER, Ada Pellegrini. A tutela dos interesses difusos. São Paulo: Max Limonad, 1984.

HOSHINO, Thiago de Azevedo Pinheiro; COELHO, Luana Xavier Pinto; MEIRINHO, Bruno César Deschamps. A usucapião especial urbana como instrumento de regularização fundiária plena: desafios para um giro hermenêutico rumo à nova ordem jurídico-urbanística. In: Revista Direito da Cidade. Vol. 9, n. 3, Rio de Janeiro, 2017, pp. 972-1001.

LIGERO, Gilberto Notário; BELINETTI, Luiz Fernando. O litisconsórcio ativo necessário no processo civil de conhecimento. In: Scientia luris, vol. 9, Londrina, 2005, pp. 155-182.

MANCUSO, Rodolfo de Camargo. A concomitância de ações coletivas, entre si, e em face das ações individuais. In: Revista da Procuradoria Geral do Estado de São Paulo. Vol. 54, pp. 45-93.

MILANO, Giovanna Bonilha. Conflitos fundiários urbanos no poder judiciário: estratégias discursivas no fundamento das decisões. In: Revista Direito da Cidade. Vol. 9, n. 4, Rio de Janeiro, 2017, pp. 2047-2071.

RIBEIRO, Benedito Silvério. Tratado de Usucapião. 7a ed. São Paulo: Saraiva, 2010. Tratado de Usucapião. Vol. 1. 5a ed. São Paulo: Saraiva, 2007. 
ROCHA, Ibraim José das Mercês. Ação de usucapião especial urbano coletivo. Lei no 10.257/2001 (Estatuto da Cidade): enfoque sobre as condições da ação e a tutela. In: Jus Navigandi, Teresina, ano 6, n. 52, nov. 2001.

SALLES, José Carlos de Moraes. Usucapião de bens móveis e imóveis. 7ạ ed. São Paulo: Revista dos Tribunais, 2010.

SANTOS, José Augusto Lourenço dos. A transformação da posse precária em posse ad usucapionem pela inversão do título da posse. In: Revista do Instituto do Direito Brasileiro. Ano 1, no 9. Faculdade de Direito da Universidade de Lisboa, Lisboa, 2012, pp. 5523-5531.

SILVESTRE, Gilberto Fachetti. A responsabilidade civil por violação à função social do contrato. São Paulo: Almedina, 2018.

THEODORO JÚNIOR, Humberto; FARIA, Juliana Cordeiro de. A tutela coletiva dos direitos individuais homogêneos: legitimação processual das associações no direito brasileiro. In: Revista Magister de Direito Civil e Processual Civil, Porto Alegre, v. 11, n. 63, p. 5-21, nov./dez. 2014.

VANIN, Fábio Scopel; HERMANY, Ricardo. Análise crítica das mudanças promovidas pela Medida Provisória n. 759/2016 na regularização fundiária do Brasil. In: Revista Direito da Cidade. Vol. 9, n. 2, Rio de Janeiro, 2017, pp. 482-516.

VILLAS BÔAS, Regina Vera; DAMASCENA, Carine Valeriano. Aspectos relevantes da história dos direitos difusos e coletivos. In: Revista Direito \& Paz. Ano 6, no. 11, Lorena, 2004.

ZANETI JR., Hermes. Processo Coletivo. Salvador: JusPodivm, 2006.

WAMBIER, Luiz Rodrigues; TALAMINI, Eduardo. Curso avançado de processo civil. Processo Cautelar e Procedimentos Especiais. Vol. 3. 14ạ ed. São Paulo: Revista dos Tribunais, 2015.

ZAVASCKI, Teori Albino. Defesa de direitos coletivos e defesa coletiva de direitos. In: Revista Jurídica. №. 212. Porto Alegre, jan. 1995, pp. 16-33. 